\title{
Experience of a pediatric HIV clinic in Guatemala City
}

\author{
Blanca Samayoa, ${ }^{1}$ Matthew R. Anderson, ${ }^{2}$ Carlos Grazioso, ${ }^{3}$ \\ Blanca Estela Rivera, ${ }^{3}$ Margo Harrison, ${ }^{2}$ William O'Brien, ${ }^{2}$ \\ and Eduardo Arathoon ${ }^{3}$
}

Suggested citation Samayoa B, Anderson MR, Carlos Grazioso C, Rivera BE, Harrison M, O'Brien W, Arathoon E. Experience of a pediatric HIV clinic in Guatemala City. Rev Panam Salud Publica. 2009;25(1):51-5.

ABSTRACT Objectives. To describe the clinical experience of a Guatemalan pediatric HIV clinic and referral center, and fill the gap in literature available on pediatric HIV in Guatemala, a country facing a growing HIV epidemic.

Methods. Analyses were performed on data available from the clinical databases maintained by the Clinica Familiar Luis Angel Garcia within the Hospital General San Juan de Dios in Guatemala City, Guatemala.

Results. From January 1997-June 2006, a total of 536 children (individuals under 13 years of age) were registered at the clinic, 54\% of them female. At the initial visit, 241 were known to be HIV infected, while 295 were known to have been exposed to HIV, but were of undetermined infection status. Of the 295 with undetermined status, serostatus was determined in 173, and $57(33 \%)$ were HIV positive. The patients came from all 24 departments of Guatemala, but the majority (64\%) was from Guatemala City. Most had perinatal exposure; three patients had been sexually exposed to HIV (all male); and the mode of infection could not be determined for six children. In the cohort of children whose infection status was initially undetermined, the provision of antiretroviral ( $A R V)$ medication (both pre-and neonatal), in addition to Cesarean section, was associated with an odds ratio of 0.06 for HIV infection $(\mathrm{P}<$ 0.001 ) when compared to children who had no interventions. Highly active antiretroviral therapy (HAART) was administered to 167 HIV-infected children. There were 44 known deaths in this cohort; no deaths occurred among the children who were not infected.

Conclusions. Pediatric HIV/AIDS is present in all parts of Guatemala. Programs to prevent mother to child transmission and to provide appropriate treatment to families living with HIV/AIDS must be a public health priority.

Key words HIV seroprevalence, child health, anti-HIV agents, Guatemala.

Facultad de Ciencias Químicas, Universidad de San Carlos de Guatemala, Guatemala City, Guatemala.

2 Department of Family and Social Medicine, Albert Einstein College of Medicine and Montefiore Medical Center, Bronx, New York, United States of America. Send correspondence to: Matthew Anderson, M.D., Department of Family and Social Medicine, 3544 Jerome Avenue, Bronx, NY, 10467, USA; telephone: +01-718-9205521; fax: +01-718-8811458; email: MattAnderson@SocialMedicine.org

3 Clínica Familiar Luis Ángel García, Hospital General San Juan de Dios, Guatemala City, Guatemala.
In 2006, the Joint United Nations Program on HIV / AIDS (UNAIDS) reported that, worldwide, there were 2.3 million children under 14 years of age living with HIV/AIDS and an additional 15.2 million orphaned by the disease. The report notes sadly that the "needs of children with HIV have been largely left out of the research agenda" (1).
The first cases of AIDS in Guatemala were identified in the early 1980s. By 2005, a total of 2700 AIDS-related deaths had been reported, and HIV prevalence was estimated to be less than $1 \%$, although the quality of epidemiologic data is poor (2). The National AIDS Program of Guatemala reports that from January 1984August 2005, there were 8658 cases of 
AIDS, $513(5.5 \%)$ of which occurred in children 14 years of age or younger. ${ }^{4}$ The National Program does not keep data on persons with HIV infection per se and reliable estimates of HIV prevalence among children in Guatemala do not exist. In the late 1990s, Guatemala's two national hospitals, the Hospital General San Juan de Dios and the Hospital Roosevelt, opened HIV/AIDS clinics. However, most women in Guatemala do not receive routine prenatal care, and thus are not tested for HIV. In 2005, a national program to prevent mother-to-child transmission was begun, but it reaches only a small proportion of pregnant women.

This paper describes the experience of one of the two national HIV reference clinics, the Clínica Familiar Luis Ángel García (hereafter "Clínica Familiar"), located within the Hospital General San Juan de Dios (hereafter "Hospital General"). Our purpose is to compile and disseminate data regarding pediatric HIV in Guatemala.

\section{MATERIALS AND METHODS}

The Clínica Familiar has been in operation since 1988 (3). It is managed by the Asociación de Salud Integral (Comprehensive Health Association), a Guatemalan non-governmental organization that has received funding and support from the Hospital General, foundations, international aid agencies, and private donors.

A clinical session dedicated to pediatrics was opened at the Clínica Familiar in 1997, under the direction of a one of the authors (CG), a specialist in pediatric infectious diseases. This was the first site to provide comprehensive HIV/AIDS care for children in Guatemala. In addition to caring for patients with HIV infection, the Clínica Familiar serves as a reference center for children with perinatal exposure to HIV, routinely following these cases until the child reaches 18 months of age when a definitive infection status can be determined.

The pediatrics session was initially available one day a week, but now functions five mornings a week. Children with identified or suspected HIV infection are referred to the Clínica Familiar's pediatric unit through a variety of sources

\footnotetext{
4 National Program on AIDS, Ministry of Health, Guatemala. Unpublished Report. Guatemala City; 2006.
}

and from throughout the country, as well as by the Hospital General and those whose parents are HIV-infected.

Free antiretroviral (ARV) treatment has been available to children at the Clínica Familiar since the late 1990s. It was initially provided through a medication recycling program, HIV Medicines for Guatemala, ${ }^{5}$ whereby unused HIV medication was obtained from infectious disease clinics in the United States of America and transported free of charge to Guatemala by volunteers. The clinic's policy was to give pediatric patients first priority when distributing the medication. Since 2001, the National AIDS Program of Guatemala has been supplying medications. In all, 167 children have received ARV in the Clínica Familiar.

\section{Patient population}

All children seen at the Clínica Familiar in January 1997-July 2006 are included in the study. Children were defined as individuals up to 13 years of age. HIV infection was diagnosed by two positive, highly-sensitive enzyme-linked immunosorbent assays and/or the presence of AIDS defining illness.

At their initial visit, children were placed into one of two groups, either HIV-exposed infants whose final serostatus was undetermined ("infection status undetermined") or children in whom HIV infection was confirmed ("HIVinfected"). Those infants whose infection status was initially undetermined were followed by the clinic until 18 months of age when a definitive infection status could be determined.

\section{Data collection}

In 2000, HIV counselors and clinicians began using standardized forms to collect demographics and laboratory data for each child; this data was regularly entered into an Epi-Info database. For years prior to 2000, demographic data is more limited and was gathered from patient roster sheets maintained by the clinic staff. Because this data was not collected in a systematic fashion, these

\footnotetext{
5 Muralles D, De La Rosa E, Paz-Garcia L, Latham B, Anderson M, Arathoon E, et al. HIV meds for Guatemala program, an alternative of medicament access for PLWA (People Living with HIV/AIDS) in a developing country. The XIV International AIDS Conference, Barcelona, Spain, Abstract no. F12266. 2002.
}

patients were not included in assessing clinical outcomes following ARV therapy or in looking at the efficacy of maternal ARV interventions on limiting vertical transmission.

\section{Laboratory tests}

Chemistry panels, radiological procedures, and ELISA tests were performed at the Hospital General's Central Laboratory. CD4 and viral load testing were done at various commercial labs when funds were available.

\section{Statistical analysis}

The data was maintained in Epi-Info version 3.2.2. Analyses were done with both Epi-Info (Centers for Disease Control and Prevention, Atlanta, Georgia, United States) and SPSS 13.0 (SPSS Inc., Chicago, Illinois, United States).

\section{Ethics}

The analysis and publication of this data was approved by the Hospital General San Juan de Dios Ethics Committee and by the Institutional Review Board at Montefiore Medical Center, Bronx, New York, United States.

\section{RESULTS}

\section{Patient population}

From January 1997-July 2006, a total of 536 patients under 14 years of age were seen by the Clínica Familiar's pediatric HIV unit. At the initial visit, 241 had known HIV infection, and 295 had been exposed in utero, but had undetermined infection status. By 1 August 2006, of the 295 with undetermined infection status, 57 had been found to be HIV-infected; 51 were lost to follow-up; 71 were still pending final serostatus; and 116 were HIV-negative. Thus, of the 536 patients, the clinic saw 298 HIV-infected children, 116 HIV-negative children, and 122 children whose serostatus remained undetermined (Table 1). The number of new cases seen at the Clínica Familiar remained stable from 2003-2005, reflecting the opening of two new pediatric HIV clinics (Hospital Roosevelt, Guatemala City; Hospital Nacional, Puerto Barrios).

Table 2 presents basic demographic data at the time of registration for both those with undetermined infection status 
TABLE 1. HIV infection status of new patients at initial visit and after testing, Clínica Familiar Luis Ángel García, Hospital General San Juan de Dios, Guatemala, January 1997-June 2006

\begin{tabular}{|c|c|c|c|c|c|c|c|}
\hline \multirow[b]{2}{*}{ Year } & \multicolumn{4}{|c|}{ Undetermined at initial visit } & \multirow{2}{*}{$\begin{array}{l}\text { HIV- } \\
\text { infected } \\
\text { at initial } \\
\text { visit }\end{array}$} & \multirow{2}{*}{$\begin{array}{c}\text { Total } \\
\text { new } \\
\text { patients }\end{array}$} & \multirow{2}{*}{$\begin{array}{c}\text { Total } \\
\text { HIV } \\
\text { infectec }\end{array}$} \\
\hline & All & $\begin{array}{l}\text { HIV non- } \\
\text { infected }\end{array}$ & $\begin{array}{c}\text { HIV } \\
\text { infected }\end{array}$ & Unknown & & & \\
\hline 1997 & 13 & 5 & 4 & 4 & 7 & 20 & 11 \\
\hline 1998 & 15 & 9 & 0 & 6 & 15 & 30 & 15 \\
\hline 1999 & 22 & 8 & 4 & 10 & 22 & 44 & 26 \\
\hline 2000 & 27 & 12 & 15 & 0 & 14 & 41 & 29 \\
\hline 2001 & 42 & 25 & 16 & 1 & 28 & 70 & 44 \\
\hline 2002 & 36 & 28 & 7 & 1 & 35 & 71 & 42 \\
\hline 2003 & 23 & 11 & 4 & 8 & 46 & 69 & 50 \\
\hline 2004 & 37 & 10 & 7 & 20 & 36 & 73 & 43 \\
\hline 2005 & 44 & 8 & 0 & 36 & 28 & 72 & 28 \\
\hline $2006^{a}$ & 36 & 0 & 0 & 36 & 10 & 46 & 10 \\
\hline Total & 295 & 116 & 57 & 122 & 241 & 536 & 298 \\
\hline
\end{tabular}

${ }^{a}$ First six months of the year.

TABLE 2. Demographic data on all patients and on those with undetermined infection status at admission to Clínica Familiar Luis Ángel García, Hospital General San Juan de Dios, Guatemala, January 1997-August 2006

\begin{tabular}{|c|c|c|c|c|}
\hline \multirow[b]{2}{*}{ Characteristic } & \multicolumn{2}{|c|}{ Infection status at initial visit } & \multicolumn{2}{|c|}{$\begin{array}{l}\text { All patients with } \\
\text { undetermined infection status }\end{array}$} \\
\hline & $\begin{array}{l}\text { HIV infection } \\
\text { uncertain }\end{array}$ & $\begin{array}{l}\text { Known } \\
\text { to be } \\
\text { HIV infected }\end{array}$ & $\begin{array}{l}\text { Determined } \\
\text { to be HIV- } \\
\text { negative (\%) }\end{array}$ & $\begin{array}{l}\text { Determined } \\
\text { to be HIV- } \\
\text { positive (\%) }\end{array}$ \\
\hline Totals & 295 & 241 & 116 & 57 \\
\hline Mean age at initial visit (years) & 0.29 & 3.35 & 0.28 & 0.48 \\
\hline Gender & $n=286$ & $n=233$ & $n=113$ & $n=55$ \\
\hline Male & $150(52.4)$ & $102(43.8)$ & $55(48.7)$ & 37 (67.3) \\
\hline Female & $136(47.6)$ & $131(56.2)$ & $58(51.3)$ & $18(32.7)$ \\
\hline Form of exposure or transmission & $n=243$ & $n=197$ & $n=94$ & $n=49$ \\
\hline Perinatal & $243(100)$ & $188(95.4)$ & $94(100)$ & $49(100)$ \\
\hline Sexual & 0 & $3(1.5)$ & 0 & 0 \\
\hline Transfusion & 0 & 0 & 0 & 0 \\
\hline Unknown & 0 & $6(3.0)$ & 0 & 0 \\
\hline Living situation & $n=155$ & $n=189$ & $n=84$ & $n=48$ \\
\hline Both parents & $78(50.3)$ & $57(30.2)$ & $43(51.2)$ & $19(39.6)$ \\
\hline Mother alone & $40(25.8)$ & $42(22.2)$ & $25(29.8)$ & $8(16.7)$ \\
\hline Father alone & $1(0.6)$ & $6(3.2)$ & 0 & $1(2.1)$ \\
\hline Grandparents & $2(1.3)$ & $24(12.7)$ & $1(1.2)$ & $1(2.1)$ \\
\hline Other family & $5(3.2)$ & $22(11.6)$ & $2(2.4)$ & $3(6.3)$ \\
\hline Orphanage & $29(18.7)$ & $38(20.1)$ & $13(15.5)$ & $16(33.3)$ \\
\hline
\end{tabular}

and those known to be infected. Children with undetermined infection status had a mean age of approximately 3.5 months; the mean for children with known infection was approximately 3.3 years. Most patients had been exposed perinatally; however, three male children had been exposed sexually.

Among those HIV-infected children for whom housing information was available (237), only $32 \%$ (76) were living with both parents; $23 \%$ (54) were in orphanages and 21\% (50) were living with a single mother. Forty-four HIVinfected patients were known to have died by the end of the study period. There were no known deaths among the 116 children who were determined to be HIV negative.

Among the 241 children who entered the clinic with known infection status, 154 were still being followed at the end of the study period, 29 had died, and 58 had been lost to follow-up. By the end of the study period, of the 295 children who had entered the clinic with undetermined infection status, 116 had been discharged as HIV-negative; 15 of the 57 HIV-infected children had died; and 122 had been lost to follow-up.
All Guatemala's 22 geographic departments were represented in the study population (Figure 1), with the majority of cases $(63.6 \%)$ originating around the capital city in Guatemala State. Patients were also seen from the neighboring countries of El Salvador and Honduras.

\section{Provision of ARV therapy}

During the study period, 167 children received ARV in the clinic. The most common regimens employed were the following triple therapies: (a) Zidovudine, Lamivudine, and Efavirenz (39\% of patients); (b) Zidovudine, Lamivudine, and Nelfinavir (17\%); (c) Stavudine, Lamivudine, and Nelfinavir (10\%); (d) Zidovudine, Didanosine, and Nelfinavir (8\%); (e) Zidovudine, Didanosine, and Efavirenz (4\%); (f) Didanosine, Stavudine, and Nelfinavir (4\%); and (g) Lamivudine, Stavudine, Efavirenz (4\%). The variety of medication regimens reflected the fact that the clinic made use of donated drugs.

Figure 2 shows paired pre- and postCD4 levels for 130 children in whom at least two CD4 tests were run. Mean CD4 increased by 240 ( $P<0.01$, paired t-test). Prior to ARV, $20 \%$ of the children had a CD4 of less than 200; after therapy this percentage was reduced to 8.3.

In 1998-2005, pregnant women being followed by the Clínica Familiar received government-supplied Zidovudine, administered using the ACTG 076 protocol (4). Since 2005, triple therapy with Lopinavir/ritonavir, Zidovudine, and Lamivudine is given to HIV-infected pregnant women; the child receives Zidovudine monotherapy. In cases where the mother has not received treatment, but the infant is diagnosed with HIV at birth, the child is given triple therapy (Lopinavir/ritonavir, Zidovudine, and Lamivudine).

\section{Impact of prenatal and perinatal interventions on vertical transmission}

Information on prenatal and perinatal care received by the mother of each pediatric patient was available for 233 of the 293 children in whom infection status was not known initially; this information was obtained from the mothers. Three interventions for Prevention of Mother-to-Child Transmission (PMTCT) were evaluated: prenatal ARV therapy, delivery by cesarean section, and neonatal ARV therapy. 
FIGURE 1. Place of birth, by department in Guatemala, for the patients new to the Clínica Familiar Luis Ángel García, Hospital General San Juan de Dios, Guatemala, January 1997-August 2006

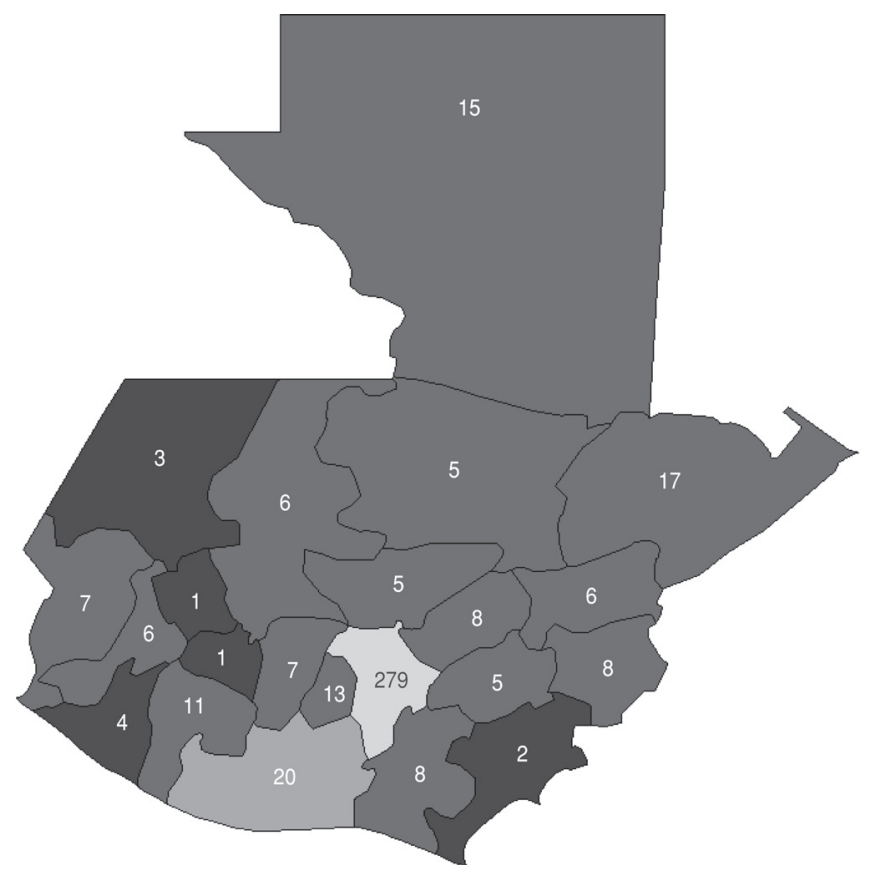

FIGURE 2. Pre- and post-antiretroviral therapy (ARV) CD4 counts in pediatric patients at the Clínica Familiar Luis Ángel García, Guatemala, January 1997-August 2006

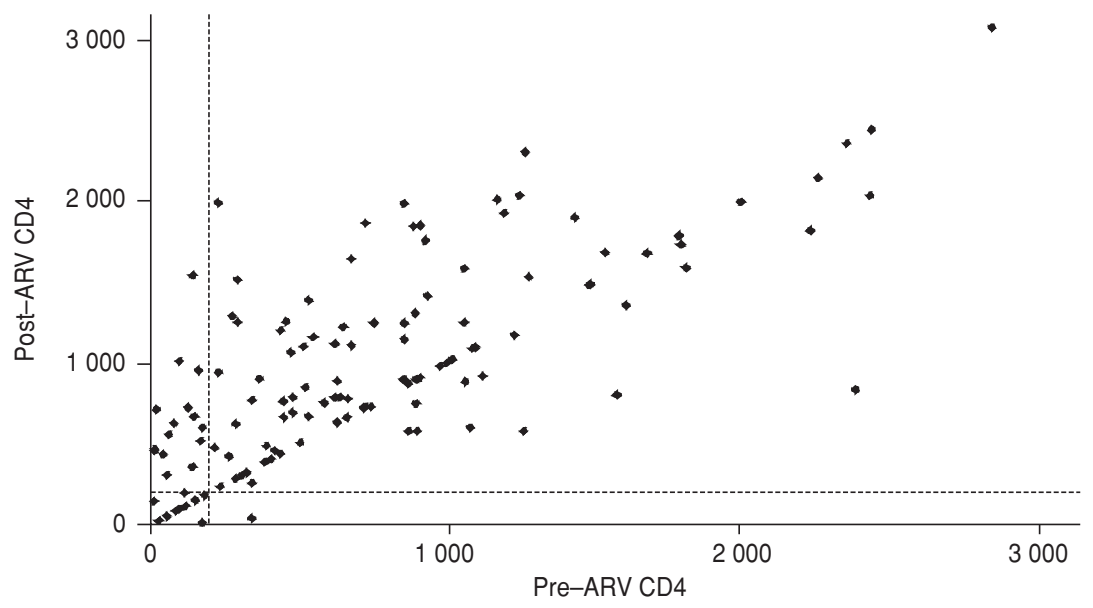

Dashed lines indicate CD4 level of 200

Of the 233 births, $60(26 \%)$ had none of the three interventions, $46(20 \%)$ involved one or two of the interventions, and 127 (55\%) involved all three. Giving birth in Guatemala City was highly associated $(P<0.001$, Pearson's Chi Square) with all three interventions; 108 of 168 $(64 \%)$ of the women giving birth in Guatemala City had had all three interventions, as compared to only 19 of the 65
(29\%) of those giving birth elsewhere in the country (Table 3 ).

Of this cohort of 233 births, a definitive diagnosis was available for 132 infants. Using the births with no interventions as a comparator, having one or two interventions was associated with an odds ratio $(\mathrm{OR})$ of $0.29(P=0.02)$ and having had all three interventions was associated with an OR of $0.06(P<0.001)$.

\section{DISCUSSION}

This paper provides the first published description of pediatric HIV in Guatemala. The broad geographic distribution of patients attending the Clínica Familiar provides evidence that HIV infection, while centered in Guatemala City, is established throughout the country. Our data suggest that prenatal ARV therapy and Cesarean sections are useful in preventing mother-to-child HIV transmission, but may not be easily available outside of Guatemala City. This is hardly surprising, but provides local data to support rapid implementation of PMTCT programs throughout the country.

Our data is limited by the fact that it was drawn from a referral population. In most areas of Guatemala, HIV testing is not available, so most cases are probably not diagnosed. Thus, our population is not broadly representative of the state of HIV infection among children in Guatemala. We drew our data from clinical records and the clinic does not have enough resources to do follow-up and verification. Approximately $10 \%$ of the population was lost to follow-up with respect to serostatus. We suspect that many more deaths occurred among the study's population, than were reported to the clinic. In addition, we have only the most limited data regarding illnesses in this cohort.

Despite these limitations, we feel that the Clínica Familiar's experience illustrates the urgent need to introduce PMTCT programs, following recommended international guidelines, throughout Guatemala (5). The use of antiretroviral therapy, the avoidance of breast feeding, and elective Cesarean sections have virtually eliminated MTCT of HIV in developed countries (6). In Guatemala, however, several major hurdles impede the provision of these services and access to prenatal care is far from universal. The WHO Reproductive Health Database estimates that in Guatemala, $14 \%$ of women receive no prenatal care and only $68 \%$ receive four or more visits (1998-1999); only $41.4 \%$ of births are attended by skilled health care personnel (2002) (7). For those patients who do receive prenatal care, access to PMTCT programs is very limited. It has only been in the past 2-3 years that PMTCT programs, supported by the Global Fund, have been fully operational in the capital city's two national hos- 
TABLE 3. Impact of three Prevention of Maternal to Child Transmission (PMTCT) interventions among 132 children in whom initial HIV infection status was undetermined, Clínica Familiar Luis Ángel García, Hospital General San Juan de Dios, Guatemala, January 1997-August 2006

\begin{tabular}{lccr}
\hline & \multicolumn{2}{c}{ Final diagnosis } & \\
\cline { 2 - 3 } & HIV negative & HIV-infected & All \\
\hline No PMTCT interventions & $20(46 \%)$ & $23(54 \%)$ & 43 \\
One or two PMTCT interventions $_{\text {Antiretroviral therapya }}{ }^{2}$ & $21(75 \%)$ & $7(25 \%)$ & 28 \\
$\quad$ Total & $57(93 \%)$ & $4(7 \%)$ & 61 \\
& $98(74 \%)$ & $34(26 \%)$ & 132 \\
\hline a & &
\end{tabular}

${ }^{a}$ Interventions were: prenatal antiretroviral therapy, neonatal antiretroviral therapy, and Cesarean section.

pitals; such programs do not exist in the rest of the country. To create them would require setting-up diagnostic and testing centers, ensuring access to ARV therapy, training personnel in the management of HIV in pregnancy and neonates, and providing the resources to do elective Cesarean section for HIVpositive mothers at facilities throughout the country. This public health infrastructure has yet to be created on a national level. Programs would need to be in place to provide HIV-positive mothers with infant formula in order to avoid breastfeeding. This has been successfully done at the Clínica Familiar.

Finally, it is estimated that $77 \%$ of indigenous women and $34 \%$ of nonindigenous women in Guatemala deliver at home, with the assistance of a midwife (8). Thus any successful PMTCT will need to collaborate successfully with Guatemala's midwives. These, then, are the challenges currently facing the public health system of Guatemala.

Acknowledgements: Margo Harrison's participation was supported by the David E. Rogers Fellowship of the New York Academy of Medicine. Matthew Anderson was supported by the Center for AIDS Research at Albert Einstein College of Medicine, Bronx, New York, United States of America.

\section{REFERENCES}

1. Joint United Nations Program on HIV/AIDS (UNAIDS). Report on the Global AIDS Epidemic. Geneva: WHO; 2006. (UNAIDS/06.20E)

2. Country Coordination Mechanism for the Republic of Guatemala: Intensification of activities in prevention and integrated care in HIV/ AIDS in vulnerable groups and priority areas in Guatemala. Geneva: Global Fund to Fight AIDS, Tuberculosis and Malaria; 2003.

3. Samayoa B, Arathoon E, Anderson M, Rodriguez J, Quattrini E, Gordillo $C$ et al. The emergence of AIDS in Guatemala: inpatient experience at the Hospital General San Juan de Dios. Int J STD AIDS 2003;14(12):810-3.
4. Connor EM, Sperling RS, Gelber R, Kiselev P, Scott G, O'Sullivan MJ et al. Reduction of maternal-infant transmission of human immunodeficiency virus type 1 with zidovudine treatment. Pediatric AIDS Clinical Trials Group Protocol 076 Study Group. N Engl J Med 1994; 331(18):1173-80.

5. World Health Organization. Antiretroviral drugs for treating pregnant women and preventing HIV infection in infant: towards universal access: Recommendations for a public health approach. Geneva: WHO; 2006.

6. Inter-Agency Task Team on Prevention of HIV Infection in Pregnant Women, Mothers and their Children. Guidance on global scale-up of the prevention of mother-to-child transmission of HIV. Geneva: WHO; 2007.

7. World Health Organization. Reproductive health indicators database. Geneva: WHO; 2008.

8. León Noriega L. Diagnóstico de situación y respuesta al VIH y sida en Guatemala: análisis y conclusiones. Guatemala City: USAID; 2008.

Manuscript received on 19 November 2007. Revised version accepted for publication on 4 August 2008.

RESUMEN Objetivos. Describir la experiencia de una clínica y centro de referencia pediátrico para el VIH en Guatemala y llenar el vacío existente en la literatura científica sobre la infección pediátrica por el VIH en ese país, donde se enfrenta una creciente epidemia por el VIH.

Experiencia de una clínica
pediátrica para el VIH en
la Ciudad de Guatemala
Métodos. Se analizaron los datos disponibles en la base de datos clínicos de la Clínica Familiar Luis Ángel García del Hospital General San Juan de Dios, Ciudad de Guatemala, Guatemala.

Resultados. Entre enero de 1997 y junio de 2006 en la clínica se registraron 536 menores de 13 años; $54 \%$ de los cuales eran niñas. En la visita inicial se sabía que 241 estaban infectados por el VIH y que 295 habían estado expuestos a ese virus aunque su diagnóstico era indeterminado. De estos, se determinó el estatus serológico de 173, de los cuales 57 (33\%) resultaron positivos al VIH. Los pacientes procedían de los 24 departamentos de Guatemala, pero la mayoría (64\%) era de la Ciudad de Guatemala. La mayoría de los pacientes había estado expuestos al VIH por la vía perinatal; tres pacientes (todos varones), por la vía sexual y no se pudo determinar la vía de infección de seis niños. En la cohorte de niños con diagnóstico inicial indeterminado, el tratamiento antirretroviral (tanto pre como posnatal) junto con el nacimiento por cesárea se asociaron con una razón de posibilidades (odds ratio) de tener la infección por el VIH de $0,06(P<0,001)$ en comparación con los niños sin estas intervenciones. El tratamiento antirretroviral de gran actividad (HAART) se administró a 167 niños infectados por el VIH. Se registraron 44 muertes en esta cohorte, ninguna en los niños sin infección.

Conclusiones. La infección pediátrica por VIH/sida está presente en todos los departamentos de Guatemala. Los programas para evitar la transmisión de madre a hijo y brindar el tratamiento adecuado a las familias que viven con $\mathrm{VIH}$ /sida son una prioridad de salud pública

Palabras clave Síndrome de inmunodeficiencia adquirida, VIH, hospitales pediátricos. Guatemala. 